\title{
Clinical Features and Treatment Results of Children with High-Risk Neuroblastoma Undergone to Autologous Stem Cell Transplantation
}

\author{
Erman ATAS ${ }^{1}$, M. Tezer KUTLUK ${ }^{2}$, Canan AKYUZ ${ }^{2}$ \\ ${ }^{1}$ University of Health Sciences, Gulhane Training and Research Hospital, Department of Pediatrics, Division of Pediatric \\ Oncology \\ ${ }^{2}$ Hacettepe University, Faculty of Medicine and Cancer Institute, Department of Pediatrics, Division of Pediatric Oncology, \\ Ankara, TURKEY
}

\begin{abstract}
As autologous stem cell transplantation has a better survival rate than conventional chemotherapy, some prognostic factors are effective on survival and event in children with high risk NBL after autologous stem cell transplantation. This is a retrospective study. We aim to evaluate the effect of clinical and treatment features of 26 patients [Newly diagnosed / Relapsed 15 (57.7\%) / 11 (42.3\%)] with high-risk neuroblastoma (NBL) undergone to autologous stem cell transplantation with Busulphan-Melphalan or CarboplatinEtoposid-Melphalan. They were included in the study between 1998 and 2015. We aim to evaluate the effect of clinical and treatment features of them on outcome of autologous stem cell transplantation. EFS and OS were $21.4 \%$ and $61.8 \%$ at 3-year, but they were $14.2 \%$ and $53 \%$ at 5-year in patients with high-risk NBL. Post-transplant PFS and OS in patients with high risk were $31 \%$ and 51.7 at 3-year.Accordingly conditioning regimen, post-transplant PFS and OS rates were $51.9 \%$ and 25\% in Bu-Mel, $45.5 \%$ and $44 \%$ in CEM group at 3-year (OS; $p=0.42$ and PFS; $p=0.10)$. Unfavorable histology ( $p=0.07, \mathrm{HR}=3.2, \mathrm{Cl}$ : 0.9-11.2) was effective factor on EFS, although it was not statistically significant. Remission status (without CR) at auto-SCT was effective factor on both PFS ( $p=0.01$, $\mathrm{HR}=4.6, \mathrm{Cl}: 1.4-14.9)$ and $\mathrm{OS}(\mathrm{p}=0.04, \mathrm{HR}=5.1, \mathrm{Cl}: 1.1-24.2)$. Too deep and long-lasting hematologic toxicity was our experience in MIBG treatment before CEM conditioning regimen compared to Bu-Mel. Any conditioning transplant regimen is not superior to each other exactly. The major factors affecting the prognosis of children with neuroblastoma seem tumor load and unfavorable histology. Before autologous stem cell transplantation, complete remission status is essential for progression free and overall survival.
\end{abstract}

Keywords: Neuroblastoma, Autologous stem cell transplantation

\section{ÖZET}

Otolog kök hücre transplantasyonu konvansiyonel kemoterapiden daha iyi bir sağkalım oranına sahip olmasına karşın konvansiyonel lehine olan iyi sonuçlar ile çelişkiler vardır. Bazı prognostik faktörler, otolog kök hücre transplantasyonundan sonra sağkalım ve olay gelişmesi üzerinde etkili olmaktadır. Bu çalışmada, busulphan-melfalan veya karboplatin-etoposid-melfalan ile otolog kök hücre transplantasyonu uygulanmış yüksek riskli nöroblastomlu 26 hastanın sonuçlar üzerine etkili klinik ve tedavi özelliklerinin etkisini değerlendirmeyi amaçladık. Yüksek riskli hastalarda üç ve beş yıllık EFS ve OS sırası ile \%21.4 ve \%14.2 ve \%61.8 ve \%53 idi. Yüksek riskli hastalarda transplant sonrası 3 yıllık PFS ve OS \%31 ve \%51.7 idi. İileştirme rejimine göre, nakil sonrası PFS ve OS oranları, Bu-Mel'de \%51.9 ve \%25, CEM'de \%45.5 ve \%44 idi (OS: $p=0.42$ ve PFS; $p=0.10)$. EFS'de olumsuz histoloji $(p=0.07, H R=3.2$, Cl: 0.9-11.2) etkili bir faktördü ancak istatistiksel olarak anlamlı değildi. Oto KHT'de remisyon durumu (tam remisyonsuz) PFS ( $p=$ 0.01, $\mathrm{HR}=4.6, \mathrm{Cl}$ : 1.4-14.9) ve OS ( $\mathrm{p}=0.04, \mathrm{HR}=5.1, \mathrm{Cl}: 1.1-24.2)$ için etkili faktördü. Bu-Mel ile karşılaştırıldığında çok derin ve uzun süren hematolojik toksisite CEM öncesi kullanılan MIBG tedavisinde tecrübemizdi. lyileştirme rejimlerinin birbirlerine herhangibir tam üstünlüğü yoktur. Nöroblastomlu çocukların prognozunu etkileyen başlıca faktörler tümör yükü ve olumsuz histolojidir. Otolog kök hücre naklinden önce, tam remisyon statüsü, progresyonsuz ve genel sağ kalım için gereklidir.

Anahtar Kelimeler: Nöroblastom, Otolog kök hücre transplantasyonu 


\section{INTRODUCTION}

Neuroblastoma (NBL) is the most common extracranial solid tumour of childhood. ${ }^{1}$ Two -year overall survival rate for Stage IV patients with conventional standard treatment regimens is reported as $30 \% .^{2}$ Mattahy et al. ${ }^{3}$ reported that autologous stem cell transplantation (auto-SCT) arm is better than conventional chemotherapy arm in the comparison of event-free survival rate (EFS) (30\% vs. $17 \%$ ). These ratios have been increased to $50 \%$ of EFS with consolidation therapies such as stem cell transplantation, maintenance and immunotherapies in today's circumstances. ${ }^{4}$ Therefore, auto-SCT is recommended as standard treatment protocol by Turkish Paediatric Oncology Group (TPOG) in high risk patients. ${ }^{5}$

As a problem, many patients who undergo to autoSCT may develop recurrence. ${ }^{6}$ Because the outcomes at best are still $50 \%$ for PFS. Simon et al. reported 56\% (253 in 451 patients) recurrence after auto-SCT in high risk NBL. ${ }^{7}$ Thus, many patients can be expected to relapse. Prognostic parameters such as stage, age at diagnosis, pathology, cytogenetic and molecular genetics that show the patients who can go worse have been studied much and found as clinically significant and relevant factors. ${ }^{8,9}$ In this study, we aim to evaluate clinical features, treatment results, and the effect of various factors on relapse and survival of the children with NBL who undergone auto-SCT.

\section{PATIENT AND METHODS}

\section{Subjects}

This is a retrospective clinical report of the treatment and outcome of high risk NBL, highlighting the role of autologous bone marrow transplantation in the treatment. The 26 patients with high risk NBL who underwent autologous stem cell transplantation were included in the study between 1998 and 2015 for the factors such as gender, age at diagnosis and transplantation, primary localization, bone involvement, cranial bone involvement, n-myc amplification, stage, relapsed or newly diagnosed, remission status at transplantation, purging status, metaiodobenzylguanidine (MIBG) treatment before auto-SCT, conditioning regimen, ra- diotherapy after auto-SCT. Approval for the study was obtained from local Ethics Committee.

This is a retrospective study. Informed consent from patients' family has been taken. Auto-SCT was done in these patients as standard of care and was not done on a study. Exclusion criteria for the subjects included the followings: (1) Patients treated only with conventional chemotherapy; (2) the subjects with missing data; (3) Age more than 18 years old.

\section{Risk Stratification and Induction Chemotherapy Protocols}

The criterias 5 for enrolment to high risk was the followings: TPOG NB 2003: Stage III, $\geq 1$ years old patient with unfavourable Shimada or Stage IV, > 1 years old patient with any Shimada; TPOG 2009: Stage IIA-IIB, $\geq 18$ months old patient with MYCN gene amplification, any $1 \mathrm{p}$ or $11 \mathrm{q}$ or $17 \mathrm{q}$ aberration and any Shimada; Stage III, 0-21 years old patient with MYCN gene amplification, any $1 \mathrm{p}$ or $11 \mathrm{q}$ or $17 \mathrm{q}$ aberration and any Shimada; Stage III, $\geq 18$ months old patient with no MYCN gene amplification, any $1 \mathrm{p}$ or $11 \mathrm{q}$ or $17 \mathrm{q}$ aberration and unfavourable Shimada; Stage IV, $\geq 18$ months old patient with any MYCN gene amplification, any $1 \mathrm{p}$ or $11 \mathrm{q}$ or $17 \mathrm{q}$ aberration and any Shimada; Stage IV, $<18$ months old patient with MYCN gene amplification, any $1 \mathrm{p}$ or $11 \mathrm{q}$ or $17 \mathrm{q}$ aberration and any Shimada; Stage IVS, <12 months old patient with MYCN gene amplification, any $1 \mathrm{p}$ or $11 \mathrm{q}$ or $17 q$ aberration and unfavourable Shimada. Before TPOG-NBL-2003 protocol, IPOG-NB-92 protocol was prepared and used in some centres in our country. However, different protocols were used in different centers. Induction regimens used in our patients were the followings:

Study Group of Japan for Advanced NBL:A: Ifosphamide $1200 \mathrm{mg} / \mathrm{m}^{2}$ for day 1 , Vincristine $1.5 \mathrm{mg} /$ $\mathrm{m}^{2}$ for day 1 , epirubicin $60 \mathrm{mg} / \mathrm{m}^{2}$ for day 3 , cisplatin $90 \mathrm{mg} / \mathrm{m}^{2}$ for day 5 was given in every 6 week. After 6 cycles; $\mathrm{C}$ and A2 were altered in every 6 weeks.C: Ifosphamide $1600 \mathrm{mg} / \mathrm{m}^{2}$ day 1 , DTIC $250 \mathrm{mg} / \mathrm{m}^{2}$ days $1-5$. and A2: Ifosphamide 1600 $\mathrm{mg} / \mathrm{m}^{2}$ for day 1 , epirubicin $60 \mathrm{mg} / \mathrm{m}^{2}$ for day 3 , cisplatin $90 \mathrm{mg} / \mathrm{m}^{2}$ for day 5 . were altered in every 6 weeks; 


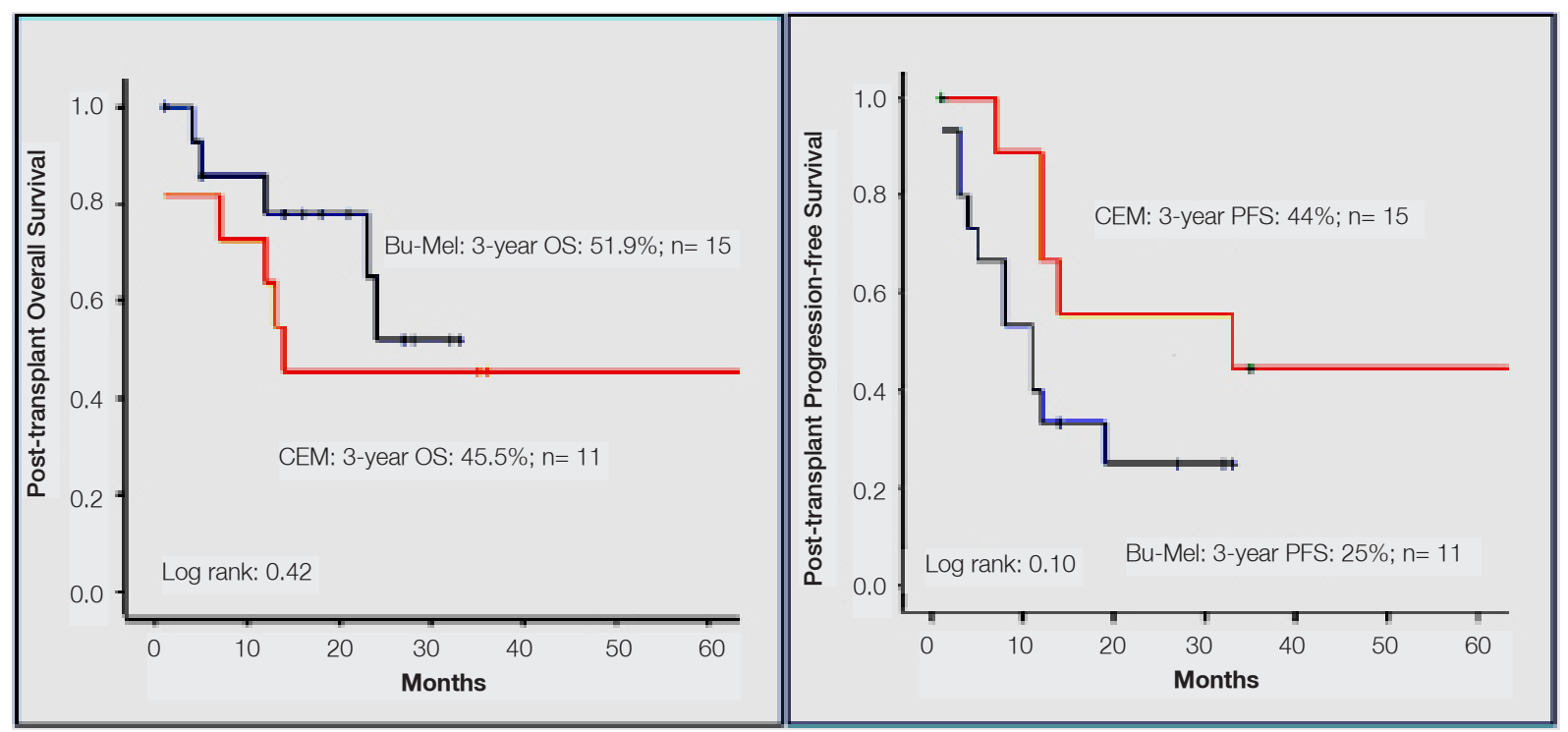

Figure 1. Comparison of post-transplant PFS and OS rates of Bu-Mel vs. CEM as conditioning regimens

Malign mesenchymal rhabdoid (MMR): Vincristine $1.5 \mathrm{mg} / \mathrm{m}^{2}$ for weeks $0-9$, Cisplatin $90 \mathrm{mg} /$ $\mathrm{m}^{2}$ for weeks $0,3,6,9$, Adriamycin $60 \mathrm{mg} / \mathrm{m}^{2}$ for weeks $0,3,6,9$, cyclophosphamide $30 \mathrm{mg} / \mathrm{kg}$ for weeks $0,3,6,9$;

TPOG-NBL-2003: A3:; Vincristine $1.5 \mathrm{mg} / \mathrm{m}^{2}$ days 1 and 5, Ifosphamide with mesna $1.8 \mathrm{~g} / \mathrm{m}^{2}$ for days $1-5$, DTIC $250 \mathrm{mg} / \mathrm{m}^{2}$ days $1-5$, adriamycin $20 \mathrm{mg} / \mathrm{m}^{2}$ for days 1-3. A5:; Cisplatin $30 \mathrm{mg} / \mathrm{m}^{2}$ days $1-5$, Cyclophosphamide $300 \mathrm{mg} / \mathrm{m}^{2}$ with mesna for days $1-5$, VP- $16150 \mathrm{mg} / \mathrm{m}^{2}$ for days 4 and 5 .

TPOG -NBL-2009: A9:; Vincristine $1.5 \mathrm{mg} / \mathrm{m}^{2}$ for days 1 and 5, Ifosphamide with mesna $1.5 \mathrm{~g} /$ $\mathrm{m}^{2}$ days $1-5$, DTIC $200 \mathrm{mg} / \mathrm{m}^{2}$ for days $1-5$, adriamycin $30 \mathrm{mg} / \mathrm{m}^{2}$ for days 4 an 5. A11:; Cisplatin 30 $\mathrm{mg} / \mathrm{m}^{2}$ for days $1-5$, Cyclophosphamide $300 \mathrm{mg} /$ $\mathrm{m}^{2}$ with mesna for days $1-5, \mathrm{VP}-1680 \mathrm{mg} / \mathrm{m}^{2}$ for days 1-4.

\section{Surgery/Biopsy}

Surgery if possible or biopsy was performed for initial treatment. In patients who were unresectable at diagnosis, surgery was done in relation to chemotherapy after six or eight cycles of induction, if possible. Autologous stem cell transplantation was performed as consolidation therapy after induction and surgery.

\section{Conditioning Regimens at Transplantation}

According to NBL protocol in our country, high risk group was stratified into conventional chemotherapy plus bone marrow transplantation or only conventional chemotherapy. We have changed transplantation regimen from Carboplatin, Etoposide and Melphalan (CEM) to Busulphan-Melphalan (Bu-Mel) due to high survival rate of Bu-Mel since 2011. CEM [Carboplatin $300 \mathrm{mg} / \mathrm{m}^{2} /$ day and etoposide $200 \mathrm{mg} / \mathrm{m}^{2} /$ day between day $(-5)$ and $(-2)$, melphalan $45 \mathrm{mg} / \mathrm{m}^{2} /$ day between day $(-8)$ and (-5) with/without MIBG treatment; If the center have opportunity to provide MIBG treatment at day -21 before transplantation with the dose of maximum $12 \mathrm{mCi} / \mathrm{kg}$ for only MIBG uptake positive at diagnosis] was used for 11 patients, but $\mathrm{Bu}$ Mel [Bu; 0.8-1.2 mg/kg/dose iv ,total 16 doses according to age between day (-7) and (-3)-Mel; 140 $\mathrm{mg} / \mathrm{m}^{2} /$ day iv at day (-1)] for 16 . GCSF $(5 \mu \mathrm{g} / \mathrm{kg} /$ day) was started post-transplant day +1 , and was used up to $5000 / \mathrm{mm}^{3}$ of WBC.

Retinoic acid which was 6 cycles in A3-A5 (TPOG-2003) and 9 cycles in A9-A11 (TPOG2009) was used as $160 \mathrm{mg} / \mathrm{m}^{2} /$ day between day 1 and day 14 every 28 days. It was started at day +90 of auto- SCT (see Figure 1). Radiotherapy was used for local control in patients with viable or residual tumour after induction chemotherapy. Whereas, the required gap between radiation and 
start of auto-SCT is 4-6 weeks in A9-A11 protocol. Radiotherapy is performed on the primary tumor localization with the doses of 26-40 Gy .

\section{Stem Cell Collection Procedures}

Stem cell was collected after third and fourth cycle of treatment via peripheral except three cases due to age status and catheter problem . G-CSF injection via subcutane way was administered at a dose of 5 microgram $/ \mathrm{kg}$ every 12 hours (at 8 o'clock am and $\mathrm{pm}$ ) between days 1 and 4. At day 5, G-CSF injection was administered at 5 o'clock am, and apheresis was performed at 9 o'clock am. If CD34 count was not enough, G-CSF was administered at (8 o'clock pm), and same procedures of 5th day were repeated on day 6 . After collection of stem cell at day 5 and 6 , sometimes day 7 , purging was done total volume of product. Stem cells were collected from bone marrow in these 3 patients. We controlled bone marrow after three cycles. Even if bone marrow was positive, we collected stem cell. At the time of collection, purging was done with CD34 positive selection in 20 patients. Un-purged product was given in 6 patients owing not to obtain CliniMACS set. CD34 positive counts before and after purging were calculated.

\section{Complete Remission (CR) and Partial Remission (PR)}

Complete remission was defined as no tumour in primary site, liver, bone, bone marrow and abdomen with normal vanil mandelic acid (VMA), lactate dehydrogenase (LDH) and neuron specific enolase (NSE). Partial remission was defined as the followings: $50-90 \%$ decrease in tumour volume, no metastasis, $50-90 \%$ decrease in all measurable metastasis, $>50 \%$ decrease in bone metastasis, only one region positivity of bone marrow evaluation, <50-90\% decrease in urine VMA, 50-90\% decrease in LDH and NSE. ${ }^{10}$

\section{Types of Outcome Measures}

Definitions used as survival terms were the followings:

Overall survival (OS): It was calculated from the start of the treatment to death from any cause. Event-free survival (EFS): It was calculated from the date to start of the treatment into the date of first event (failure to achieve CR, relapse or death from any cause).

Posttransplant OS: It was calculated from the day of the transplant to death from any cause.

Post-transplant progression-free survival (PFS): For patients achieving stable disease without signs of progression, it was calculated from the day of transplant to the date of next relapse, or from the date of randomization for post CR questions

\section{Statistical Analysis}

Statistical analyses were performed using the SPSS software version 15.0. Descriptive analyses were presented using medians for variables. Kaplan-Meier methods and log rank tests were used in analysis. Risk factors, which mentioned above were analyzed as prognostic factors on survival rate with Cox regression analysis. Variables with $\mathrm{p}<0.05$ values were shown in univariate analysis, and were included in multivariate analysis for model. A p-value less than 0.05 were considered to show a statistically significant result.

\section{RESULTS}

The clinical features of patients at diagnosis and at/after transplant were shown in Table 1 and 2, respectively. Average number of stem cell count ( given to the patients) was $4.1 \pm 2.8 \times 10^{6} / \mathrm{kg}(0.6$ 19.9). Average engraftman times after autologous transplantation were the followings: Neutrophile= $24.8 \pm 16.7$ (8-75) days; Trombocyte $=27.9 \pm 17.7$ (10-75) days; Erythrocyte $=23.1 \pm 15.1$ (11-73) days. MYC-N was studied in 13 of 26 patients. Four patients (30\%) had amplified MYC-N. Only two (one of them newly diagnosed, one of them relapsed) of patients had MIBG treatment as a conditioning regimen. The other 9 patients had MIBG treatment before auto-SCT as consoliation therapy. Three/five-year EFS and OS in patients with high risk NBL were $21.4 \% / 14.2 \%$, and $61.8 \% / 53 \%$ respectively. Post-transplant PFS and OS in patients with high risk NBL were $31 \%$ and 51.7 at 3-year, respectively. Accordingly conditioning regimen, post-transplant OS and PFS rates were 51.9\% and 


\begin{tabular}{|c|c|c|}
\hline Features & Units & Median (Range) \\
\hline Age at diagnosis & years & 3 (9 months-16 years) \\
\hline LDH & IU/L & $687(112-4214)$ \\
\hline ESR & $\mathrm{mm} / \mathrm{h}$ & $77(70-85)$ \\
\hline Ferritin & $\mathrm{ng} / \mathrm{ml}$ & $376(171-1214)$ \\
\hline \multirow[t]{2}{*}{ VMA } & $\mathrm{mg} / \mathrm{g}$ creatinine & $27(7.6-478)$ \\
\hline & Category & n (\%) \\
\hline Sex & Male/Female & $16(61.5 \%) / 10(38.5 \%)$ \\
\hline \multicolumn{3}{|c|}{ Localizations of primary tumor } \\
\hline & Adrenal gland & 24 (92.2\%) (11 right, 13 left) \\
\hline & Paraaortic & 1 (3.9\%) \\
\hline & Cervical & 1 (3.9\%) \\
\hline Bone involvement & Yes/No & $23(88.5 \%) / 3(11.5 \%)$ \\
\hline Cranial bone involvement & Yes/No & $12(46.2 \%) / 14$ (53.8\%) \\
\hline MYCN status & Amplified/Unknown/Negative & $4(15.4 \%) / 13(50 \%) / 9(34.6 \%)$ \\
\hline Histology & Favourable/Unfavourable & $6(23.1 \%) / 20(76.9)$ \\
\hline Stage & IV/III & $25(96.1 \%) / 1$ (3.9\%) \\
\hline Risk group & High & 26 (100\%) \\
\hline \multicolumn{3}{|l|}{ Regimens of induction } \\
\hline \multirow[t]{4}{*}{ First line } & A9-A11 & $17(65.4 \%)$ \\
\hline & A3-A5 & $7(26.8 \%)$ \\
\hline & MMR & 1 (3.9\%) \\
\hline & JANB & $1(3.9 \%)$ \\
\hline \multirow[t]{2}{*}{ Second line } & ICE & 10 (90.9\%) \\
\hline & TCV & $1(9.1 \%)$ \\
\hline \multirow[t]{2}{*}{ Third line } & A3-ICE & $1(50 \%)$ \\
\hline & ICE & $1(50 \%)$ \\
\hline
\end{tabular}

$25 \%$ in $\mathrm{Bu}-\mathrm{Mel}, 45.5 \%$ and $44 \%$ in CEM group at 3 -year (OS; $\mathrm{p}=0.42$ and PFS; $\mathrm{p}=0.10$ ). (see Figure 1). Too deep and long-lasting hematologic toxicity was our experience in MIBG treatment before CEM. Engraftment days were longer in CEM (64\%) conditioning regimen compared to $\mathrm{Bu}-\mathrm{Mel}$ (26\%). Any differences was not found between newly diagnosed and relapsed patient who underwent to auto-SCT in both OS $(50.2 \%$ vs $54.9 \%$, p= $0.88)$ and PFS (40.2\% vs $22.2 \%, \mathrm{p}=0.58)$.

Unfavorable histology $(\mathrm{p}=0.07, \mathrm{HR}=3.2, \mathrm{CI}$ : 0.911.2) and cranial bone involvement $(\mathrm{p}=0.08, \mathrm{HR}=$ 2.3, CI: 0.8-6.1) were possible independent factors on EFS, but poor histology was effective factor on EFS after multivariate analysis, although it was not statistically significant. Remission status (without
$\mathrm{CR})$ at auto-SCT ( $\mathrm{p}=0.01, \mathrm{HR}=4.6, \mathrm{CI}: 1.4-14.9)$ and unfavorable histology $(\mathrm{p}=0.04, \mathrm{HR}=8.1, \mathrm{CI}$ : 1.1-63.5) were found as independent possible factors on PFS in univariate analysis. After multivariate analysis, remission status (without $\mathrm{CR}$ ) at auto-SCT ( $\mathrm{p}=0.01, \mathrm{HR}=4.6$, CI: 1.4-14.9) was effective factor on PFS. Remission status (without $\mathrm{CR})$ at auto-SCT $(\mathrm{p}=0.04, \mathrm{HR}=5.1, \mathrm{CI}: 1.1-24.2)$ and relapse after transplant $(\mathrm{p}=0.08, \mathrm{HR}=2.1$, CI: 0.9-4.4) were possible independent factors on post-transplant OS. After multivariate analysis, remission status (without CR) at auto-SCT $(\mathrm{p}=0.04$, $\mathrm{HR}=5.1, \mathrm{CI}: 1.1-24.2$ ) was effective factor on OS (see Table 3).

Three-year EFS in patient with high risk NBL was $10 \%$ in group of unfavorable histology and $50 \%$ in 
International Journal of Hematology and Oncology

\begin{tabular}{|c|c|c|}
\hline Features & Category & $\mathbf{n}$ \\
\hline Status at transplant & Newly diagnosed/Relapsed & $15(57.7 \%) / 11(42.3 \%)$ \\
\hline Patients refereed from another centre & Yes/No & $19(73.1 \%) / 7(26.9 \%)$ \\
\hline Source of stem cell & Peripheral/Bone marrow & 23 (88.5\%)/3 (11.5\%) \\
\hline Complete remission at transplant & Yes/No & $16(61.5 \%) / 10(38.5 \%)$ \\
\hline Yes/No & $20(76.9 \%) / 6(23.1 \%)$ & \\
\hline MIBG treatment before transplant & Yes/No & $9(34.6 \%) / 17(65.4 \%)$ \\
\hline CEM with MIBG & & 3 \\
\hline CEM without MIBG & & 8 \\
\hline Bu-Mel with MIBG & & 6 \\
\hline Bu-Mel without MIBG & & 9 \\
\hline Conditioning regimen & CEM/Bu-Mel & $11(42.3 \%) / 15(57.7 \%)$ \\
\hline Additional treatment & 13-cis retinoic acid/No & 23 (88.5\%)/3 (11.5\%) \\
\hline Pre-transplant radiotherapy & Yes/No & $4(15.4 \%) / 22(84.6 \%)$ \\
\hline \multirow[t]{2}{*}{ Radiotherapy after transplant } & Yes/No & 7 (26.9\%)/19 (73.1\%) \\
\hline & Unit & Median (Range) \\
\hline Age at transplant & years & $5(2-17)$ \\
\hline \multicolumn{3}{|l|}{ Count of CD34 } \\
\hline Before purging & x106/kg & $4.9(1.6-19.5)$ \\
\hline After purging & x106/kg & $3.4(0.6-12.9)$ \\
\hline \multicolumn{3}{|l|}{ Engraftment day* } \\
\hline Neutrophils $>0.5 \times 10 \square / L$ & day & $19(8-75)$ \\
\hline CEM & & $21(11-75)$ \\
\hline Bu-Mel & & $18(8-40)$ \\
\hline Platelets (without transfusion) $>20 \times 10 \square / L$ & day & $20(10-75)$ \\
\hline CEM & & $29(12-75)$ \\
\hline Bu-Mel & & $17(10-55)$ \\
\hline Erythrocyte & day & $18(11-73)$ \\
\hline CEM & & $30(11-73)$ \\
\hline \multicolumn{3}{|l|}{ Bu-Mel } \\
\hline Event-free survival & months & $13(4-108)$ \\
\hline Overall survival & months & $29(12-212)$ \\
\hline Post-transplant progression free survival & months & $12(1-170)$ \\
\hline Post-transplant overall survival & months & $17(1-170)$ \\
\hline
\end{tabular}

*, First of three consecutive days with the indicated blood cell levels Bu-Mel, Busulphan-Melphalan; CEM, carboplatin- etposidemelphalan; MIBG, metaiodobenzylguanidine

favourable $(\mathrm{p}=0.06)$. Three-year post-transplant PFS and OS rates were $58.8 \%$ and $81.8 \%$ in patients with $\mathrm{CR}, 8 \%$ and $23.8 \%$ in patients without CR (PFS; $p=0.004$, OS; $p=0.02$ ) (see Figure 2).

\section{DISCUSSION}

Neuroblastoma is the most common nonlymphohematopoetic childhood tumor after central nervous tumors, and account for about $7.29 \%$ of pedi- atric malignancies. ${ }^{1}$ The treatment of NBL must be multi-disciplinary, and sometimes may be too difficult for clinicians and patients due to resistance and recurrence of disease. Some prognostic factors can help to decide the treatment intensity and schedule in these patients. Auto-SCT is one of the treatment modalities of solid tumors. It is also used in the treatment of NBL, especially in highrisk group to achieve remission and improve the survival rates to higher level. 
International Journal of Hematology and Oncology

Table 3. Effects of somepredictors on clinical course of neuroblastoma

\begin{tabular}{|c|c|c|c|c|c|c|c|}
\hline & \multirow[b]{2}{*}{ Predictors } & \multicolumn{3}{|c|}{ Univariate analysis } & \multicolumn{3}{|c|}{ Multivariate analysis } \\
\hline & & Category & $\mathbf{p}$ & $95 \% \mathrm{Cl}$ & $\mathbf{p}$ & HR & $95 \% \mathrm{Cl}$ \\
\hline \multirow[t]{2}{*}{ Post-transplant PFS } & Remission status at transplant & Others/CR & 0.01 & $1.4-14.9$ & 0.01 & 4.6 & $1.4-14.9$ \\
\hline & Unfavorable histology & Yes/No & 0.04 & $1.1-63.5$ & & & \\
\hline \multirow[t]{2}{*}{ Post-transplant OS } & Remission status at transplant & Others/CR & 0.04 & $1.1-24.2$ & 0.04 & 5.1 & $1.1-24.2$ \\
\hline & Relapse after transplant & Yes/No & 0.08 & $0.9-4.4$ & & & \\
\hline \multirow[t]{2}{*}{ EFS } & Unfavorable histology & Yes/No & 0.07 & $0.9-11.2$ & 0.07 & 3.2 & $0.9-11.2$ \\
\hline & Cranial bone involvement & Yes/No & 0.08 & $0.8-6.1$ & & & \\
\hline
\end{tabular}

$\mathrm{Cl}$, confidence interval; CR, complete remission; EFS, event-free survival; HR, hazard ratio; OS, overall survival ; PFS, progressionfree survival

Males have a slightly higher incidence than females. ${ }^{11}$ This is compatible with our features. Male/ female ratio was found as $16 / 10=1.6$ in this study. Gender cannot be counted as prognostic factors. ${ }^{9}$ Likewise, we did not find gender as prognostic factors.

Generally, the outcome of NBL depends on the type, localization, histopathological aggression of tumour, stage, age and MYCN status. ${ }^{7}$ Neuroblastoma with aggressive, advanced-stage and metastatic disease is the most challenging status of the treatment. In our study, undifferentiated histology and cranial bone involvement were found as pos- sible prognostic factor for event in patients with high-risk NBL. Despite statistically insignificance, we think clinically that patient with poor histology was effective on relapse of patients $(\mathrm{p}=0.07, \mathrm{HR}=$ 3.2). Common prognostic factors were not found as effective factor in our study due to low number of patient. However, high rate of abdominal localization, bone involvement, unfavorable histology, stage IV, high age and level of LDH, ESR, ferritin and VMA were compatible with poor prognosis of these patients. MYCN was found as $15.4 \%$, but unknown status was about $50 \%$. The rate of amplified MYCN may be more than $15.4 \%$. Thus, we did not evaluate as poor prognostic factor.

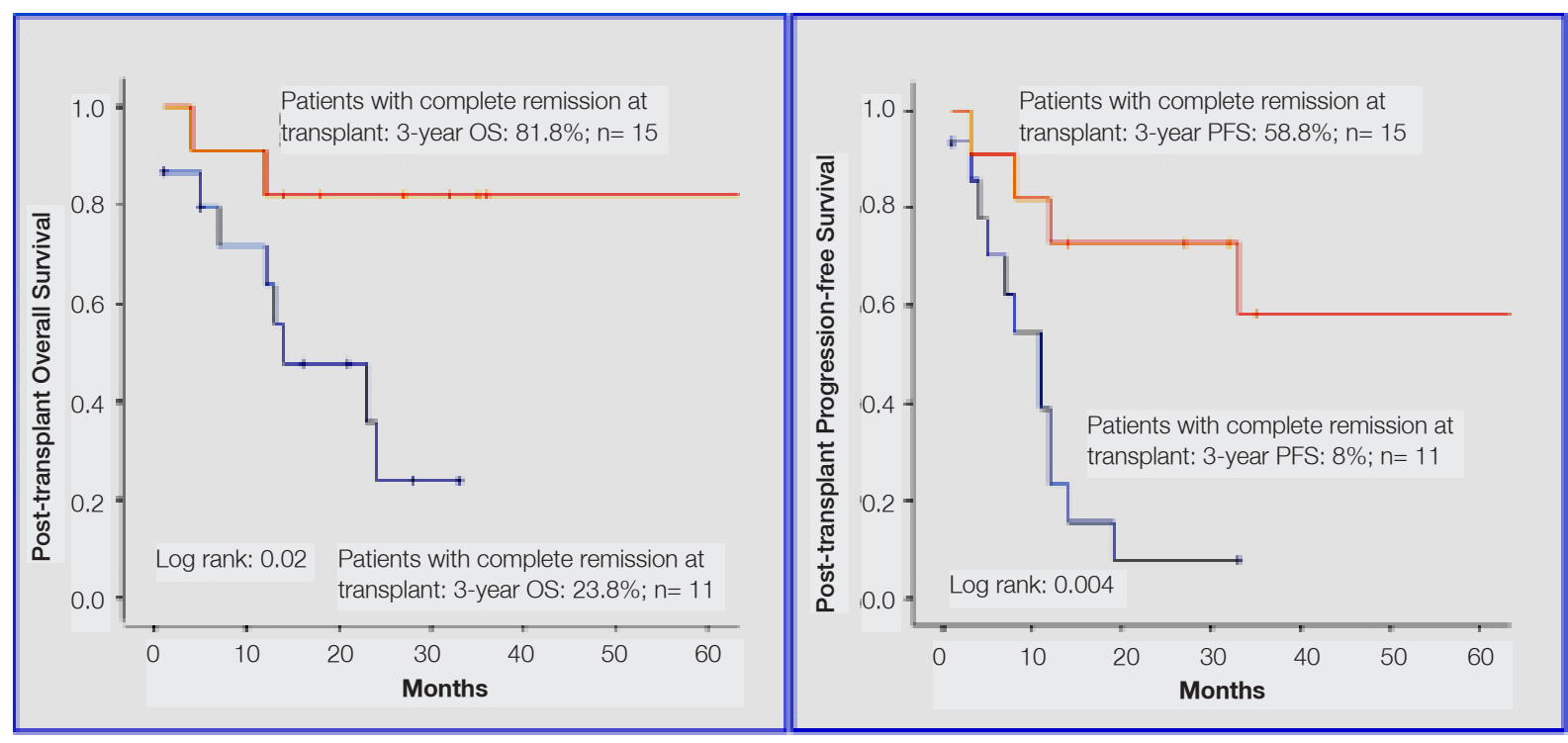

Figure 2. Post-transplant PFS and OS rates in patients with complete remission at transplant or not 
The EFS and OS for NBL are only 30\% for high risk NBL 2. Improvements have been reported by several large randomized controlled studies (3-year EFS; for auto-SCT: 47\% vs for conventional chemotherapy: 31\%). ${ }^{12,13,14}$ In our study, 3 and 5-year EFS and OS in patients with high risk NBL were $21.4 \%$ and $14.2 \%$, and $61.8 \%$ and $53 \%$, respectively. Although EFS rate was too low, OS rate was within acceptable rate. In our study, $57.7 \%$ of patients were in newly diagnosed group, and $42.3 \%$ were in relapsed group. Any difference was not found between newly diagnosed and relapsed patient who underwent to auto-SCT in both OS $(50.2 \%$ vs $54.9 \%, \mathrm{p}=0.88)$ and PFS (40.2\% vs $22.2 \%, \mathrm{p}=0.58)$. Chemosensitivity is more effective in this result. In addition, OS and PFS rates of newly diagnosed patients were acceptable level compared to results of international study.

Auto-SCT arm (30\%) is better than conventional chemotherapy arm (19\%) in the comparison of EFS. ${ }^{3}$ This ratio has been reached to $50 \%$ of EFS with therapies such as Bu-Mel stem cell transplantation. ${ }^{4}$ Our PFS rate was $31 \%$, and compatible with Matthay et al. ${ }^{3}$ However, 3 and 5-year EFS in the conventional chemotherapy arm of TPOGNBL- 2003 are 33\% and 29\%; 3 and 5 year OS are $50 \%$ and $38 \%$. In auto-SCT arm, 3 and 5-year EFS are $28 \%$ and $16 \% ; 3$ and 5 year OS are $39 \%$ and $31 \%$ 5. After this protocol, TPOG-NBL-2009 has been started since 2009. Three-year result of TPOG-NBL-2009 in conventional chemotherapy arm is $53 \%$ for OS and $43 \%$ for EFS. ${ }^{15}$. Our study is part of TPOG-2003 and 2009. The result of TPOG-NBL 2009 has been evaluated as acceptable despite decreased dose intensity and period. These results showed that auto-SCT had not superiority to conventional chemotherapy, but the rate of EFS increased from $21 \%$ to $31 \%$ in our study. Auto-SCT can give additive effect on progression. Yalcin et al. ${ }^{16}$ reported that myeloablative therapy worked in improvement of event-free survival. We think that additive effect of auto-SCT cannot be ignored. Moreover, auto-SCT is more useful before relapse and progressive stage of NBL .

Remission status at transplantation and unfavorable histology for PFS and remission status at transplantation and relapse after transplantation for OS were found as possible prognostic factors. How- ever, other remission status rather than CR was 4.6 times negative effective on progression and 5.1 times negative effective on survival (OS; $\mathrm{p}=0.04$, $\mathrm{HR}=5.1)$ and PFS $(\mathrm{p}=0.01, \mathrm{HR}=4.6)$. Patients with $\mathrm{CR}$ at transplantation had high survival and low event rates (PFS: $58.8 \%$ vs $8 \%$; OS: $81.8 \%$ vs $23.8 \%$ ). Low number of patients was our limitation to evaluate survival rates accurately.

Although different regimens may be used as conditioning phase of auto-SCT in different groups, CEM is used and recommended by Children's Oncology Group (COG). ${ }^{12}$ However, International Society of Paediatric Oncology European Neuroblastoma Group (SIOPEN) and European bone marrow transplantation (EBMT) are used Bu-Mel and recommended as more effective than others. ${ }^{17}$ As a result of a prospective study in 2011 by SIOPEN, Bu-Mel is reported as better than CEM conditioning regimen in OS analysis (OS; 60\% vs $48 \%$ ). The rate of relapse or progression is significantly lower in Bu-Mel than CEM (47\% vs $60 \%$ ). Three-year event-free survival in stage IV patients is $43 \%$ for Bu-Mel and $29 \%$ for CEM. ${ }^{17}$ This abstract has been revised and published. Three-year EFS and 5-year OS have been reported as 50\% and $54 \%$ in Bu-Mel group vs $38 \%$ and $41 \%$ in CEM group (PFS; $\mathrm{p}=0.0005$, OS; $\mathrm{p}=0.001) 4$. Our posttransplant OS and PFS rates (Bu-Mel; 51.9\% and $25 \%$ vs CEM; $45.5 \%$ and $44 \%$; PFS; $\mathrm{p}=0.42$, OS; $\mathrm{p}=0.10$ ) were comparable level with international studies owing to improvement in treatment regimen and opportunity of auto-SCT. Although the overall survival rates for children with high risk NBL were within acceptable limits, the PFS rates of Bu-Mel (25\% vs $55.6 \%)$ were much lower than OS rates. Factors with tumour biology and features which we did not find as prognostic predictor may be more effective than $\mathrm{CR}$.

In addition to effectiveness of these regimens, the toxicities of them are other problem. We used MIBG treatment in nine cases before auto-SCT. However, only two of them were undergone MIBG treatment at day -21 before stem cell infusion, but the others were undergone MIBG treatment in relapsed protocol. Too deep and long-lasting hematologic toxicity was our experience in MIBG treatment before CEM conditioning regimen 18 . These two patients dead due to intracranial and gastro- 
intestinal haemorrhage. However, we did not observe these toxicities in Bu-Mel. Our conditioning regimen was changed to $\mathrm{Bu}-\mathrm{Mel}$ due to low toxicity and high survival rates. MIBG treatment can be used after the evaluation of patient at post-transplant day +100 . If MIBG uptake were detected, auto-SCT treatment would be consolidated with MIBG treatment. Length of engraftment time was longer in CEM group than Bu-Mel. Because CD34 positive count was higher in $\mathrm{Bu}-\mathrm{Mel}$ group than CEM group both before purging $(7.9 \times 106 / \mathrm{kg}$ vs $\left.3.8 \times 10^{6} / \mathrm{kg}, \mathrm{p}=0.01\right)$ and after purging $(4.9 \times 106 / \mathrm{kg}$ vs $\left.2.9 \times 10^{6} / \mathrm{kg}, \mathrm{p}=0.04\right)$. Advantage of purging is not reported..$^{19}$ In our study, purging was not found as prognostic factor. In addition, status of purging and distribution of patients (newly diagnosed and relapsed) between Bu-Mel and CEM was not already different (Purging; $\mathrm{p}=0.66$, Distribution of patients; $p=0.43$ ). Thus, CD34 count was the significant factor on engraftment time. CD34 positive count was not associated with MIBG treatment. Opioid requirement was high in CEM group and adolescent owing to mucositis.

Patients with isotretinoin maintenance therapy had a higher EFS and OS 3. 13-cis retinoic acid was used approximately 6-15 months after auto-SCT. Additional immunotherapy with anti-GD2 and cytokines as GMCSF with isotretinoin are taught to have benefit for prevention of recurrence. AutoSCT is not suggested to improve outcome due to high benefit of anti-GD2 consolidation. ${ }^{20}$ In addition, there is no superiority of allogeneic transplantation for survival besides toxicity. However, graft versus NBL mention in a literature is intriguing. ${ }^{21}$ In our study, we did not use immunotherapy consolidation after auto-SCT and induction therapy. Allogeneic SCT was not performed. Despite intensive multimodality therapy, nearly $40 \%$ of patients remain with disease-free. ${ }^{22}$ More intensive therapies over a long duration time, best chemotherapy combination with stem cell rescue, haploidentical transplantation, immunotherapy, targeted autologous T-cells, NBL vaccines, targeted therapy for genetic mutations or for increasing apoptosis, antiangiogenic treatment, bisphosphonates and MIBG therapy are under investigation. We think immunotherapy will be a more important position of NBL treatment in the future.
Result of conventional chemotherapy is similar to auto-SCT in according to TPOG protocol. Nevertheless, the autologous transplantation is clinically effective treatment for NBL. Since the our study group consisted of both relapsed and newly diagnosed patients Especially, it should be used and tried in treatment of high-risk NBL. In addition, any conditioning SCT regimen is not superior to each other exactly. High event and progression rates after auto-SCT are very significant problem. The major factor affecting the prognosis of children with NBL seems tumor load. Importance of remission status prior to SCT confirmed in this study was the only risk factor for progression and survival after SCT. Treatments that significantly decrease the tumor volume before auto-SCT may improve the survival rate. Especially in patients with unfavorable histology, development of new methods to treat NBL without event is necessary. Randomized prospective large scaled studies can be done for further investigation to improve the survival rates and preventing the late relapses.

\section{REFERENCES}

1. Kutluk MT, Yesilipek A. Turkish National Pediatric Cancer Registry 2002-2008 (Turkish Pediatric Oncology Group and Turkish Pediatric Hematology Society). J Clin Oncol 1006710067, 2013.

2. Canete A, Gerrard M, Rubie H, et al. Poor survival for infants with MYCN-amplified metastatic neuroblastoma despite intensified treatment: the International Society of Paediatric Oncology European Neuroblastoma Experience. J Clin Oncol 27: 1014-1019, 2009

3. Matthay KK, Reynolds CP, Seeger RC, et al. Long-term results for children with high-risk neuroblastoma treated on a randomized trial of myeloablative therapy followed by 13-cisretinoic acid: a children's oncology group study. J Clin Oncol 27: 1007-1013, 2009

4. Ladenstein R, Potschger U, Pearson AD, et al. Busulfan and melphalan versus carboplatin, etoposide, and melphalan as high-dose chemotherapy for high-risk neuroblastoma (HRNBL1/SIOPEN): an international, randomised, multi-arm, open-label, phase 3 trial. Lancet Oncol 18: 500-514, 2017.

5. Olgun N, Cetingul N, Kansoy S, et al. The Turkish Pediatric Oncology Group Neuroblastoma Treatment Protocol-2009. . 1st edition. Inciralti- Izmir, TPOG, 2009: 1-170. http://www. tpog.org.tr/uploads/15_09_2009.pdf 
6. Simon T, Berthold F, Borkhardt A, et al. Treatment and outcomes of patients with relapsed, high-risk neuroblastoma: results of German Trials. Pediatr Blood Cancer 56: 578-583, 2011.

7. Simon T, Berthold F, Borkhardt A, Kremens B, De Carolis B, Hero B. Treatment and outcomes of patients with relapsed, high-risk neuroblastoma: results of German trials. Pediatr Blood Cancer 56: 578-583, 2011.

8. Cohn SL, Pearson AD, London WB, et al. The international neuroblastoma risk group (INRG) classification system: an INRG task force report. J Clin Oncol 27: 289-297, 2009.

9. Maris JM, Hogarty MD, Bagatell R, Cohn SL. Neuroblastoma. 369: 2106-2120, 2007.

10. Brodeur GM, Pritchard J, Berthold F, et al. Revisions of the international criteria for neuroblastoma diagnosis, staging and response to treatment. Prog Clin Biol Res 385: 363-369, 1994.

11. Hale G, Gula MJ, Blatt J. Impact of gender on the natural history of neuroblastoma. Pediatr Hematol Oncol 11: 91-97, 1994.

12. Matthay KK, Villablanca JG, Seeger RC, et al. Treatment of high-risk neuroblastoma with intensive chemotherapy, radiotherapy, autologous bone marrow transplantation, and 13-cis-retinoic acid. Children's Cancer Group. N Engl J Med 341: 1165-1173, 1999.

13. Berthold F, Boos J, Burdach S, et al. Myeloablative megatherapy with autologous stem-cell rescue versus oral maintenance chemotherapy as consolidation treatment in patients with high-risk neuroblastoma: a randomised controlled trial. Lancet Oncol 6: 649-658, 2005.

14. Pritchard J, Cotterill SJ, Germond SM, et al. High dose melphalan in the treatment of advanced neuroblastoma: results of a randomised trial (ENSG-1) by the European Neuroblastoma Study Group. Pediatr Blood Cancer 44: 348-357, 2005.

15. Cecen E, Varan A, Sevinir B, et al. Türk Pediatrik Onkoloji grubu (TPOG) Nöroblastom protokolü (TPOG-NBL-2009) Yüksek risk Konvansiyonel Kemoterapi kolu tedavi sonuçlari (SP-10). The 22nd National Cancer Congress, Antalya, April 19-23, 2017, P: 277.

16. Yalcin B, Kremer LC, Caron HN, van Dalen EC. High-dose chemotherapy and autologous haematopoietic stem cell rescue for children with high-risk neuroblastoma. Cochrane Database Syst Rev 2013: CD006301.

17. Ladenstein RL, Poetschger $U$, Luksch R, et al. Busulphanmelphalan as a myeloablative therapy (MAT) for high-risk neuroblastoma: Results from the HR-NBL1/SIOPEN trial. J Clin Oncol 29: 2-2, 2011.

18. Atas E, Kesik V, Kismet E, Koseoglu V. 1311-Metaiodobenzylguanidine conditioning regimen in children with neuroblastoma undergoing stem cell transplantation. Pediatr Transplant 17: 407-408, 2013.
19. Kreissman SG, Seeger RC, Matthay KK, et al. Purged versus non-purged peripheral blood stem-cell transplantation for high-risk neuroblastoma (COG A3973): a randomised phase 3 trial. Lancet Oncol 14: 999-1008, 2013.

20. Kushner BH, Ostrovnaya I, Cheung IY, et al. Lack of survival advantage with autologous stem-cell transplantation in highrisk neuroblastoma consolidated by anti-GD2 immunotherapy and isotretinoin. Oncotarget 7: 4155-4166, 2016.

21. Hirayama M, Azuma E, Araki M, Komada Y, Nakagawa A. Evidence of Graft-versus-Tumor Effect in refractory metastatic neuroblastoma. Transplantation 82: 142-144, 2006.

22. Brodeur GM, Hogarty MD, Mosse YP, Maris JM. Noroblastoma. In: Pizzo PAPoplack DG, (eds). Principles and Practice of Pediatric Oncology. Philadelphia, Lippincott Williams \& Wilkins, 2011: 886-922.

\section{Correspondence:}

Dr. Erman ATAŞ

Sağlık Bilimleri Üniversitesi

Gülhane Eğitim ve Araştırma Hastanesi

Pediatrik Onkoloji Bilim Dalı

Etlik, ANKARA / TURKEY

Tel: (+90-312) 3044374

Fax: (+90-312) 3044381

e-mail: eatasdr@gmail.com 